\title{
Det sociala arvet i ny belysning - socialbidrag och försörjningsvillkor
}

\author{
STEN-ÅKE STENBERG \& CARL HÅRD AF SEGERSTAD
}

\begin{abstract}
I alla tider har det funnits en oro för att den behovsprövade hjälpen kan ha negativa effekter på hjälptagarna. Man har menat att den utvecklar en "understödstagaranda" och att den har "incitamentshämmande« effekter. Vi prövar här om socialbidraget har några effekter mellan generationerna så att barn som växer upp i familjer som fär socialbidrag själva löper en större risk att bli socialbidragstagare. Analysen sker med hjälp av data från Projekt Metropolit som ger oss möjlighet att följa barn födda i Storstockholm àr 1953 ända fram till vuxen ålder år 1983.
\end{abstract}

Med undantag för trettiotalskrisen har andelen socialbidragstagare i Sverige under nittonhundratalet pendlat mellan fyra och sju procent av befolkningen. Den sedan 1991 dramatiskt ökande arbetslösheten har

Sten- $\AA$ ke Stenberg är docent i sociologi vid Institutet för social forskning. Han har främst forskat om frågor rörande social marginalisering som vräkningar. Idag leder han ett forskningsprojekt om arbetslöshet och social marginalisering. Carl Hård af Segerstad är fil. kand. i sociologi vid Stockholms universitet. Efter examen forskade han om socialbidragsfrågor på Centrum för utvärdering av social arbete. Han är idag verksam på Högskoleverket med analys och uppföljning av grundutbildningen inom den svenska högskolan. lett till att kostnaderna för socialbidragen accelererat och den behovsprövade hjälpen står åter i fokus för politiken. Debatten om det behovsprövade socialbidraget har långa traditioner. En av de vanligast förekommande frågorna har gällt bidragets effekter på den enskildes vilja och förmåga att försörja sig. Många har här hävdat att det kan ha negativa effekter som leder till att den enskilde passiviseras och förlorar viljan att försörja sig. Vi skall här knyta an till den diskussionen genom att jämföra hur det går för barn som vuxit upp i familjer som fått socialbidrag, med dem som inte kommit i kontakt med socialbidrag. Vi utnyttjar det uni- 
ka datamaterialet inom Projekt Metropolit som ger oss möjlighet att under trettio år följa en hel åldersgrupp svenskar födda i Stockholm år $1953^{1}$. Frågeställningen är om barn som vuxit upp i familjer med socialbidrag själva löper en större risk att som vuxna bli socialbidragstagare. Har socialbidraget i uppväxtfamiljen hjälpt dem eller har det istället lett till att de själva som vuxna fått försörjningsproblem? Kan vi hos dem spåra det som förr kallades "understödstagarandau och som idag benämns "incitamentshämmande effekter»?

Vi inleder med en kort historisk tillbakablick på hur den behovsprövade hjälpen uppfattats i Sverige. Därefter följer en sammanfattning av samhällsvetenskapliga teorier på området. Sedan prövar vi en statistisk modell där både kort- och långsiktiga faktorer vävs samman för att förklara socialbidragsbehovet som vuxen. Avslutningsvis diskuterar vi resultaten i ljuset av den svenska samhällsutvecklingen under efterkrigstiden och med sikte på framtiden.

\section{Fattigdom och behovsprövat socialbidrag över generationerna}

Fattigvård och välgörenhet har historiskt varit starkt knutna till kyrkans verksamhet. Fattigvården kan ursprungligen knytas till kristendomens krav på "goda gärningar" men gåvan var främst en moralisk plikt för

1 Projekt Metropolit har byggts upp av professor Carl-Gunnar Janson vid sociologiska institutionen, Stockholms universitet. Se Janson (1984) för en detaljerad beskrivning av projektet. givaren och inte en rätt för mottagaren. Därmed kom de fattiga att behandlas som andra klassens medborgare. De utrustades med tiggarpass och sågs ofta som ett hot mot samhällsordningen ${ }^{2}$.

I början av 1900-talet gick professor Gustaf F. Steffen (1912:16), Sveriges troligen förste sociolog och tidvis socialdemokratisk riksdagsman, till ett rasande angrepp på sin tids fattigvård: "Fattigvårdsinstitutionen är till hela sitt väsen totalt oförmögen att förebygga det nedsjunkande under ett sunt ekonomiskt minimum, varigenom fattigjonet slutligen uppstår. Och i stället för att planmässigt höja och återupprätta de sjunkna, straffar och degraderar den dessa, så att de, rent psykologiskt och socialt sett, efter behandlingen på fattighuset ofta hava svårare att stiga upp igen över fattigdomsstrecket, än fallet kanske var innan de kommo i beröring med fattigvården. Fattigvården jälper oss ej det minsta att bli av med fattigdomseländet som social massföreteelse - precis lika litet som den privata välgörenheten och den absolut oreglerade ekonomiska konkurrensen göra det. Snarare hava alla tre visat sig vara goda fattigdomskonserverande samhällsfaktorer." Oaktat den ålderdomliga språkdräkten ter sig Steffens argument aktuella också i det sena nittonhundratalet. Även idag finns det en tydlig oro för socialvårdens negativa verkningar på människor-

2 Det har dock också inom kyrkan funnits en positiv inställning till samhällets fattiga. En kristen försonar sig med sitt öde och är flitig. I bibeln uttrycks detta främst i det nya testamentet som till exempel i Lukas (6:20): „Saliga ni som är fattiga, er tillhör Guds rike", eller "Men ve er som är rika ni har nu fått era goda dagar.»(Lukas 6:24). 
nas försörjningsvilja, som kanske främst tar sig uttryck i debatten om socialbidragsnormernas storlek (se t.ex. ESO 1994). Steffen kritiserade den ålderdomliga fattigvården och argumenterade istället för en modern socialpolitik. Hans kritik kom från vänster och grundade sig inte på en föreställning om att de fattiga skulle vara lata. Men fattigvården har också kritiserats från de som haft utgångspunkten att de fattiga är lata och att de måste tvingas till arbete.

Särskilt i ekonomiskt svåra tider, när kostnaderna för den behovsprövade hjälpen växer, ökar intresset för bidragens effekter på hjälptagarnas beteende. Under 1930-talet utvecklade till exempel professor Gösta Bagge, riksdagsman och ledare för högern 1935-1944, (1930:265) tanken vid sina socialpolitiska föreläsningar på Socialinstitutet i Stockholm: "All erfarenhet ger vid handen att understöd av vad slag de vara må kunna underminera de karaktärsegenskaper hos människorna, som äro de viktigaste förutsättningarna för allmänt och enskilt välstånd, nämligen individens driftighet, skötsamhet, arbetssamhet och sparsamhet. När människorna finna, att de kunna lita till andras hjälp, vänja de sig ifrån att försöka hjälpa sig själva; och när de se, att andra i ungefär samma ställning som de själva icke behöva anstränga sig att säkerställa sin försörjning, slappas deras egna ansträngningar till självförsörjning. Erfarenheterna visa också att en sådan process blir kumulativ och tillväxer i styrka oavbrutet."

Den socialdemokratiske riksdagsledamoten Verner Hedlund (Riksdagens protokoll AK 1941, 23/4) beskrev i ett anförande i riksdagens andra kammaren 1941 hjälptagarna på följande sätt: "I de flesta större kommuner känner man igen den där asociala typen, som generation efter generation parasiterar på samhället. Dessa människor har en panisk förskräckelse för arbete och försöka på alla möjliga sätt få sin försörjning genom det allmänna. De föda barn, som få växa upp i en olämplig miljö och som, då de nått den ålder, att de borde kunna försörja sig, följa föräldrarnas exempel att parasitera på samhället.»

I en genomgång av likartade föreställningar på det här området pekar professor Gunnar Inghe (1960: 548) på att en variant av "understödstagaranda" skulle vara "den påstådda benägenheten hos en del understödstagare, sjukförsäkrade m.fl. att slå sig till ro, när de väl fått hjälp och börjat bli vana därvidu.

Med ett modernt språkbruk talar man numera inte om understödstagaranda utan istället om bidragens »incitamentshämmande» effekter. Calmfors (1993: 146) skriver till exempel följande om arbetslöshetsförsäkringens utformning: "Ett högt inkomstskydd i arbetslöshetsförsäkringen måste vara mycket begränsat $i$ tiden om tillräckliga incitament att undvika långtidsarbetslöshet ska upprätthållas.» Socialbidragens nivå antas också styra anspråksnivåerna för löner och andra sociala ersättningar och när man vill påverka dessa menar många att man skall börja med socialbidragen: "Det finns flera motiv för att se över socialbidragsnivån. Ett uppenbart och viktigt motiv är att vi vill försöka sänka de krav på marknadsinkomst och reservationslön som den implicerar." (ESO 1994:227) 


\section{Forskning om långvarigt socialbidragsberoende}

När det gäller forskning om långvarig fattigdom är det naturligt att ta utgångspunkt i USA. Inkomstskillnaderna är där betydligt större än i Sverige och den amerikanska socialpolitiken är genom sin koncentration på behovsprövad hjälp i större utsträckning inriktad mot de fattigaste i befolkningen. Intresset för sociala reformer har varit svagt och uppmärksamheten har istället till stor del riktats mot att kontrollera överutnyttjande och fusk. Amerikansk socialpolitisk forskning har också fokuserat på fattigdom och behovsprövad hjälp (Korpi 1980). Intresset för den behovsprövade hjälpens långsiktiga inverkan på individen har ökat under nittonhundratalets sista decennier och en del av forskningen har kommit att handla om riskerna för att fattigdom och hjälpbehov överförs mellan generationerna (Duncan m.fl 1988; Gottschalk 1992, 1996; Hill 1985; Levy 1980; McLanahan 1988; McLanahan \& Bumpass 1988; McLanahan, Astone \& Marks 1991; Pepper 1995; Rank \& Cheng 1995; Rein \& Rainwater 1978; Santiago 1995$)^{3}$.

Förklaringar till varför bidragsberoende skulle kunna överföras mellan generationerna kan i huvudsak uppdelas i strukturella respektive kulturella ansatser. De strukturella ansatserna lägger tonvikten vid sociala faktorer med familjens ekonomiska styrka i centrum, medan de kulturella riktar intresset mot attitydernas och värderingarnas betydelse för barnets utveckling. Den ekono-

3 Se Moffitt 1992 för en kritisk granskning av forskningen. miska fattigdomshypotesen (the economic deprivation thesis), ursprungligen utvecklad av Becker och Tomes (1979), är ett exempel på en strukturell förklaring (Hill and Duncan 1987). Hypotesen antar att de flesta föräldrar är intresserade av sina barns välfärd men då de har olika stora resurser kommer barnens förutsättningar att variera mellan olika familjer. Förklaringen antar alltså att det inte finns ett direkt samband mellan socialbidrag under uppväxten och behovet av socialbidrag som vuxen. Den ökade risken att bli socialbidragstagare går istället i arv via barnens dåliga materiella förutsättningarna.

I studier av slumbefolkningen i fattiga länder utvecklade den amerikanske antropologen Oscar Lewis (1968) en kulturell förklaring till fattigdomen. Han menade att de fattiga uppvisade fyra kännetecken: bristande deltagande i samhällets institutioner, minimal social organisation över familjenivån, avsaknad av barndom som en skyddad fas i livet och en upplevelse av fatalism och hjälplöshet. I sin uppmärksammade bok "The Other Americau förespråkar Harrington (1962: 162) liknande synsätt. »Taken as a whole, poverty is a culture. Taken on the family level, it has the same quality. These are people who lack education and skill, who have bad health, poor housing, low levels of aspiration and high levels of mental distress." Förklaringen har också utnyttjats för att förklara risken att bidragsberoende överförs mellan generationerna. Bidraget antas då ha en självständig effekt på den nya generationens risk att behöva socialbidrag och sägs påverkar människors attityder negativt så att de blir initiativlösa och arbetsovilliga. 
Under 1980-talet och början av 1990-talet intensifierades kritiken av den behovsprövade hjälpen i USA. Samhällsforskare som Charles Murray (1984) lade huvudansvaret för den ökande fattigdomen på socialpolitiken och då i synnerhet den behovsprövade hjälpen. Kritiken fick god grogrund i konservativa politiska kretsar och i slutet av år 1996 genomdrevs en ny lagstiftning som dramatiskt begränsar fattiga amerikaners möjligheter att få långvarig behovsprövad hjälp ${ }^{4}$.

Bristen på datamaterial som tillåter operationaliseringar av bidragstagarnas attityder till arbete och bidrag, har lett till att forskningen om sambanden mellan attityder och människors vilja att söka socialbidrag har utvecklats långsamt i Sverige. Per Kempe (1976) studerade under 1970-talet hur olika attityder påverkade viljan att söka socialbidrag. Resultaten visade att både negativa attityder till socialbidraget och till hjälptagarna minskade viljan att själv söka bidrag. I en klientundersökning av Bergmark (1991) framkom att ett stort engagemang i arbete och en negativ inställning till socialbidrag hängde samman med korta bidragsperioder. Det var dock oklart om det var attityderna som direkt påverkade bidragstidens längd eller om en lång tid med bidrag ledde till negativa attityder till arbete respektive positiva attityder till socialbidrag.

Gustav Jonsson var en föregångare när det gäller studier av hur sociala problem kan överföras mellan generationerna. Han följde under 1950- och 1960-talet de intagna ung-

4 Se Wilson (1996:168-169) för en bakgrund till den nya lagstiftningen domarna på behandlingshemmet Skå två generationer tillbaka i tiden och utvecklade teorin om det "sociala arvetu där han fogade samman strukturella, kulturella och personliga förklaringar till sociala problem. Där framträdde tydligt att föräldrarnas uppväxtvillkor liknande de uppväxtvillkor de själva skapade för sin barn. Jonsson fann också ett samband mellan föräldrarnas och barnens inställning till arbete och försörjning. Han pekade särskilt på skolk från skolan som en av de viktigaste faktorerna när det gäller att förutse "missanpassning senare i livet» och det gäller särskilt anpassningen till arbetslivet (Jonsson 1969).

Det är inte bara föräldrarnas ekonomiska förhållanden och attityder som påverkar barnen. Även mer personliga faktorer kan spela en viktig roll i uppfostran. Smith (1991) har i en undersökning baserad på Projekt Metropolit visat att uppfostringsideologier som ger stort utrymme åt kontrolltänkandet och styrning på bekostnad av värme, har en negativ inverkan på barnens skolprestationer och vilja att söka högre utbildning. Redan hos barnet kan det finnas liknande ärvda eller förvärvade personliga faktorer som kan spela en viktig roll för deras möjligheter att klara sig som vuxna. Det gäller här olika typer av socialisationsproblem som utlevande beteende och impulsstyrt handlande samt andra disciplinproblem (Andersson 1976; Gottfredson och Hirschi 1990; Jonsson 1969).

Vi skall avslutningsvis diskutera en modell som Korpi (1971) utvecklade för att för-

5 Till Skå kom de ungdomar som var alltför besvärliga för att kunna tas om hand av den lokala socialvården. 
klara varför individer söker socialbidrag. I den svenska forskningen om socialbidrag har modellen utnyttjats av flera författare (Halleröd 1991; Bergmark 1991; Salonen 1993). Korpi delade upp faktorerna i grundläggande, betingande och utlösande ${ }^{6}$. De grundläggande faktorerna utgörs av de krafter som skiktar människorna i den sociala strukturen och som skapar social ojämlikhet. De betingande faktorerna placerar individen i samhällets socio-ekonomiska struktur och på verkar därmed sannolikheten att han eller hon skall behöva söka hjälp. Här har vi sådant som kön, ålder, uppväxtvillkor, familjebakgrund och klasstillhörighet. De utlösande faktorerna är de som slutligen fäller avgörandet när individen bestämmer sig för att söka hjälp på socialbyrån. Det är händelser eller omständigheter som minskar individens resurser eller ökar hans behov. Här har vi till exempel sjukdom, arbetslöshet, skilsmässor och ytterligare försörjningsansvar för barn.

I princip utlöses behovet av socialbidrag när en betingande faktor förändras. Det kan gälla ökad familjestorlek, arbetslöshet, sjukdom som nedsätter arbetskapaciteten eller familjeupplösning. Empiriska prövningar har pekat ut arbetslösheten som den vanligaste orsaken, men även sjukdom, hög skuldsättning och för små inkomster nämns i flera studier som utlösande faktorer (Inghe 1960; Korpi 1971; Tengvald 1974; Bergmark 1991; Salonen 1993; Stenberg 1996). I vår undersökning finns inte några uppgifter om sådana förändringar av betingande faktorer och vi kommer därför inte att diskutera ut-

6 Termen utlösande faktorer använde Inghe redan 1960. lösande faktorer mer ingående. Korpis förklaring är direkt kopplad till samhällsstrukturen. Människans personliga förutsättningar och handlande, det Inghe kallade "personligheten" (Inghe 1960: 483), saknas däremot i Korpis modell. I Metropolitundersökningen finns flera variabler som ger oss möjlighet att inkludera sådana personliga och även kulturella faktorer i analysen.

\section{Risken för långvarigt socialbidragsberoende över generationerna}

Vi skall nu med hjälp av Metropolitundersökningens data undersöka i vilken utsträckning vad vi ovan kallat strukturella, kulturella och personliga faktorer påverkar sannolikheten för att barn från familjer med socialbidrag själva kommer att bli socialbidragstagare. Metropolitprojektets data består av samtliga barn födda år 1953 som bodde i Storstockholm 1963. Gruppen följdes genom intervjuer och med utdrag från register under perioden 1953-1983. Det finns en rik information om deras uppväxtvillkor, samt föräldrarnas sociala och personliga förhållanden, inklusive attityder till uppfostran och samhällsfrågor (Janson 1984). Tack vare att undersökningen är prospektiv har data en stor tillförlitlighet. Det gäller naturligtvis främst faktorer som attityder och personliga förhållanden som är svåra att mäta retrospektivt. Data grundas på en hel befolkningsgrupp och skiljer sig därför från klientundersökningar vilka riskerar att överskatta problemen då urvalet gjorts från gruppen som har problem. Vår analys bygger på den så kallade Familjeundersökningen (FU) där ett urval av 4000 
mödrar till barnen i Metropolitmaterialet intervjuades år 1968. De fick svara på frågor som bland annat behandlade attityder till olika delar av samhället. I våra analyser ingår 3049 individer sedan de som inte fanns i Stockholmsområdet under hela barndomen 1953-70 och de som emigrerat eller avlidit före 1983 exkluderats. ${ }^{7}$ Uppgifter om socialbidrag i vuxen ålder insamlades av projektet endast under åren 1982 och 1983. Vi har därför en lucka utan data rörande socialbidrag för åren 1971-1981.

Behov av socialbidrag är oftast kortvarigt (Salonen 1993) men det finns också människor som behöver hjälp under långa perioder. Sammanlagt var det 26 procent av Metropolitundersökningens barn födda i Stockholm år 1953 som växte upp $i$ familjer som någon gång under barnens uppväxt fick socialbidrag och under åren 1982-83 var det nio procent av de då vuxna barnen som själva fick socialbidrag. Bland de som åren 198283 erhöll socialbidrag hade drygt fyra av tio vuxit upp $i$ en familj som någon gång under deras uppväxt fått socialhjälp, medan det bland dem som klarade sig utan socialbidrag bara var två av tio som kom från sådana fa-

7 Familjeundersökningens urval på 4,021 individer stratifierades med hjälp av ett begåvningstest där samtliga med det fem procent högsta respektive fem procent lägsta resultatet togs med och bland de övriga 90 procenten inkluderades var femte individ. Av de svarande var 98 procent mödrar till barnen (Janson 1975). Stenberg (1994) gjorde en liknande undersökning på hela Metropolitmaterialet. Replikationen av Stenbergs modell på datamaterialet $\mathrm{i}$ FU krävde vissa förändringar. Detta beror på det minskade antalet observationer i FU jämfört med hela Metropolitmaterialet (Hård af Segerstad 1996). miljer. Annorlunda uttryckt fick sjutton procent av barnen från familjer med socialbidrag själva socialbidrag 1982-83, motsvarande andel bland dem vars föräldrar aldrig fick socialbidrag var det endast sex procent (Stenberg 1994). Risken för barn som vuxit upp med socialbidrag att själva bli socialbidragstagare var alltså tre gånger så hög som för andra barn.

Strukturella, kulturella såväl som personliga faktorer kan ha påverkat den här observerade överrisken för barn från socialbidragsfamiljer att själva få socialbidrag som vuxna. Vårt intresse här gäller i första hand frågan om bidraget i uppväxtfamiljen skapar en understödstagaranda, om det har en incitamentshämmande effekt över generationerna. För att kunna pröva detta försöker vi här konstanthålla så många som möjligt av de faktorer som vid sidan av socialbidraget $\mathrm{i}$ uppväxtfamiljen kan påverka bidragsberoendet senare i livet. Därför renodlar vi den kategori av hushåll som fick socialbidrag utan att ha några andra indikatorer på problem och jämför dem med barn som vuxit upp i familjer utan socialbidrag. Om vi då finner att barn från socialbidragsfamiljer inte har större risk än andra barn från familjer utan socialbidrag att själva få socialbidrag talar detta mot påståendena om bidragens negativa effekter.

Det är också viktigt att understryka att våra resultat endast gäller för en kohort ungdomar födda år 1953 i Storstockholm. Man kan naturligtvis tänka sig att det hade sett annorlunda ut för barn som växte upp i andra delar av landet och för ungdomar från andra årgångar. Men projekt Metropolits data är unika och det finns tyvärr inga andra möjligheter att på ett så här detaljerat

Stenberg \& Hård av Segerstad: Det sociala arvet i ny belysning... 
sätt studera socialbidraget över flera generationer.

Undersökningen innefattar följande faktorer verksamma under uppväxten och i vuxen ålder:

\section{Faktorer under uppväxten:}

Socialbidrag (registerutdrag för åren 195372 kodat till 1 om socialbidrag någon gång utbetalades under uppväxten och 0 i de fall familjen aldrig fick socialbidrag).

Ekonomisk situation (familjens genomsnittliga inkomst före skatt år 1963').

Inställning till skolk (mäter föräldrarnas inställning till arbetsnormen. Mammorna fick svara på frågan: „Har Ni låtit henne/ honom stanna hemma från skolan fast hon/han inte varit sjuk, och i så fall, har det hänt någon gång eller flera gånger?» Svarsalternativen var aldrig, ja en gång, eller ja flera gånger, och har kodats som 1 om barnet vara hemma).

Inställning till religion (följande fråga ställdes för vardera föräldern: "Är Ni religiöst intresserad? " och " ̈̈r Er man religiöst intresserad?" Svaren fördelas på en femgradig skala från mycket ointresserad till mycket intresserad. Variabeln är en sammanslagning av frågorna, där religiöst intresse givits värdet 1).

Uppfostringsideologier (koncentreras till frågan om föräldrarna anser att barnen skall tillåtas stor frihet under uppväxten. De fick ta ställning till påståendet: "Det är inte bra att barnet får stor frihet». Svarsalternativen var alldeles rätt, i stort sett rätt, varken eller, i stort sett fel, eller all-

8 I detta belopp är barnbidrag och bidragsförskott inräknade. deles fel. Föräldrar som svarat att påståendet var alldeles eller i stort sett rätt klassificeras som inriktade mot en uppfostran med tonvikt på kontroll och disciplin).

Utlevande beteende (mäts med frågan »Har Du blivit utkörd från klassrummet för någonting $\mathrm{Du}$ gjort? « Svarsalternativen var likadana som på frågan om föräldrarnas inställning till skolk).

Begåvning (resultat från ett test i sjätte klass av barnens verbala, rumsliga och numeriska förmåga).

Betyg $i$ årskurs 6 (medelbetyget multiplicerat med 100 och kan variera mellan 0 och 500).

Utbildningsgrad (om individen genomgått gymnasiet eller högre utbildning har variabeln värdet 1 , $i$ annat fall 0 ).

\section{Faktorer vid vuxen ailder:}

Inkomst (före skatt under perioden 19821983. Inkomster för eventuella sammanboende finns inte tillgängliga).

Antal barn (avser förhållandet 1983 och kommer från folkbokföringen).

Boendesituation (avser 1980, variabeln är indelad i fyra kategorier; gift / sambo, ensamstående, boende i föräldrahemmet, eller annan form av boende ${ }^{9}$. Uppgifterna är hämtade folk- och bostadsräkningen).

Arbetad tid (individens anknytning till arbetsmarknaden under perioden 19821983. Variabeln har två värden: 1 vid 20 timmar eller mer och 0 om arbetstiden understiger 20 timmar per vecka).

Sjukskrivningdagar (registrerade dagar av

9 Annat boende kan vara på en institution, hos syskon, hos mor/farföräldrar etc. 
ersättning från försäkringskassan under åren 1982-1983).

I Tabell 1 (se nästa sida) presenteras fördelningen av de variabler som ingår $i$ analysen. På samtliga variabler utom antal barn och kön skiljer sig socialbidragstagare från de som inte fick bidrag 1982 1983.

\section{Resultat}

Eftersom den beroende variabeln endast har två värden (fått eller inte fått socialbidrag 1982-83) kommer vi i de följande analyserna att utnyttja logistisk regression (för beskrivningar av metoden se t.ex. Aldrich and Nelson 1984 och Hosmer and Lemeshow 1989). Det går inte att direkt jämföra styrkan på koefficienterna i den logistiska regressionen, men de anger effektens riktning och signifikanstestas som $i$ en vanlig linjär regression. De kan dock räknas om till sannolikheter och vi illustrerar i bilagan detta med ett exempel.

Analysen innefattar en rad faktorer verksamma både under uppväxten och i vuxen ålder och som i modellen mäts med deras enkla effekter (Tabell 2). Resultaten visar att pojkar löper en större risk att bli socialbidragstagare, dåliga resultat på begåvningstestet i sjätte klass ökar risken att bli socialbidragstagare och höga betyg minskar risken liksom utbildning utöver grundskolan. Föräldrarnas inkomst har inte en statistiskt signifikant effekt på risken att bli socialbidragstagare, men variabeln har en förväntad negativ riktning. Variabelns svaga signifikans kan eventuellt bero på att föräldrarnas socialbidrag också finns med i modellen. Barn som vuxit upp i religiösa hem har en lägre risk att få socialbidrag och barn som vars uppfostran har präglats av sträng disciplin och hård kontroll löper större en större risk att bli socialbidragstagare.

Faktorerna i vuxen ålder har i samtliga fall förväntade effekter. Risken att behöva söka socialbidrag minskar med arbetstidens längd och med inkomstens nivå. Sjukdom leder till en större risk att behöva socialbidrag och många barn i hushållet ökar också sannolikheten för bidrag. De olika hushållstyperna är jämförda med parförhållanden. Ensamboende har då en mycket större risk än par att behöva socialbidrag och än större risk löper den som klassificerats i "övriga" hushållstyper. Här finner vi dem som bor på institutioner, hemma hos syskon, är hemlösa, etc. Interaktionen mellan kön och inkomst visar att män med låga inkomster har en högre sannolikhet att behöva socialbidrag än kvinnor med motsvarande inkomster.

För att testa socialbidragets självständiga effekt har vi i Tabell 2 delat upp materialet genom att kombinera tre olika faktorer till åtta olika grupper. På så sätt prövar vi samspelet (interaktionen) mellan socialbidrag i uppväxtfamiljen - barnets beteende och mammans attityd. Indelningen har gjorts med hjälp av tre variabler som vardera har två olika värden (ja eller nej): Har uppväxtfamiljen fătt socialbidrag?; Har barnet blivit utvisat från klassrummet någon gång?; Har mamman tillåtit att barnet stannat hemma utan lov? Jämförelsegruppen är de som inte har vuxit upp med socialbidrag, som inte blivit utvisade från klassrummet och som inte har en mamma som accepterat skolk. Den gruppen har därför givits värdet noll (0) i tabellen och de andra gruppernas värden visar avståndet från denna jämförelse- 
Tabell 1

Orsaksfaktorernas fördelning inom grupperna socialbidragsmottagare 1982-83, respektive icke socialbidragstagare 1982-83 (procent och genomsnitt). Antal observationer $=3049$.

Bidragsmottagare 1982-83 Icke bidragsmottagare 1982-83

Kön

274 st. (9\%) 2775 st. (91\%)

Kvinnor

49

48

Män

51

52

Faktorer under uppväxten

Socialbidrag under uppväxten 1953-70

Familjen fick bidrag

39

18

Familjen fick ej bidrag

61

82

Familjeinkomst -63

15

27

Familjens inställning till skolk

Aldrig accepterat

Accepterat max I gång

Accept skolk flera gånger

Familjens intresse för religion

Stort intresse

Varken eller

Inte intresserad

Inställning till disciplin under uppfostran

Hård disciplin

Varken eller

Mycket frihet

Utvisad från lektion

Aldrig inträffat

Inträffat en gång

Inträffat mer än en gång

Begåvning

Betyg àk 6

Utbildning

Bara nioårig grunddskola

Mer än nioårig grundskola

Faktorer vid vuxen ảlder

Egen inkomst 1982-83

Antal egna barn 1983

\section{Hushållssituation}

Gift/Sammanboende

Ensam

Föräldrar

Annat boende

\section{Arbetad tid}

Mindre än 20h/vecka $\quad 30$

Merän 20h/vecka $\quad 70$ 
grupp. Risken att bli socialbidragstagare är större i nästan alla andra grupper. Den allra högsta risken löper barn som vuxit upp i en familj med socialbidrag och som har blivit utvisade från klassrummet samt har mammor som accepterat skolk. Det är inte så förvånande då det är den mest "belastade» gruppen.

Gruppindelningen ger oss möjlighet att pröva om socialbidraget har någon självständig effekt över generationerna. Av Tabell 2 framgår att effekten $(0.065)$ knappt skiljer sig från jämförelsegruppen och att den inte är statistiskt signifikant. Bland barn som växt upp i familjer där föräldrarna aldrig accepterade skolk och som själva aldrig varit utvisade från någon lektion ökar alltså socialbidrag under barndomen inte i nämnvärd

\section{Tabell 2}

Faktorer sompåverkar risken att behöva socialbidrag i vuxen ålder ${ }^{1}$

\begin{tabular}{|c|c|c|c|c|c|}
\hline \multicolumn{3}{|c|}{$\begin{array}{l}\text { Strukturella förhållanden under uppväxten och } \\
\text { föräldrarnas attityder under uppväxten. }\end{array}$} & \multicolumn{3}{|c|}{ Strukturella förhållanden som vu } \\
\hline Variabel & Logit & S.E & Variabel & Logit & S.E \\
\hline Kön & $3,044 * *$ &, 692 & Arbetad tid &,- 322 & \\
\hline Begåvning &,$- 041 *$ &, 016 & Sjukdagar &, $010 * *$ &, 00 \\
\hline Utbildning &,$-\left.56\right|^{*}$ &, 223 & Antal barn &, $318 * *$ & ,09 \\
\hline Familjeinkomst $-53^{2}$ &,- 192 & 104 & Boendesituation & & \\
\hline Betyg åk 6 &,$- 003 *$ &, 002 & Ensam & 1,309** & 19 \\
\hline Religion &,$- 114 * *$ &, 044 & Hos föräldrar & ,200 & ,39 \\
\hline \multirow[t]{2}{*}{ Uppfostran } &,$- 163 *$ & 073 & Övrigt & $1,768 * *$ & 27 \\
\hline & & & Egen inkomst &,$- 348 * *$ & 11 \\
\hline Konstant &,- 184 & 683 & Inkomst*kön &,$- 722 * *$ &, 17 \\
\hline
\end{tabular}

Interaktionen mellan socialbidrag under uppväxt, föräldrarnas inställning till skolk, och utvisning från lektion

\section{Föräldrars inställning till skolk Utvisad från lektion}

Nej

Aldrig accepterat

Accepterat
Socialbidrag någon gång 1953-70

Logit $^{\text {Nej }}$ S.E. Logit $\quad$ S.E

0

0,065 , 454

$\begin{array}{lcccc}\text { Ja } & , 340 & , 246 & 1,295 * * & , 264 \\ \text { Nej } & , 937 * & , 321 & , 854 & , 499 \\ \text { Ja } & 1,109 * * & , 292 & 1,388 * * & , 340\end{array}$

| *= signifikant på fem procents nivån, **= signifikant på en procents nivån.

2 För att undvika problem med att variabler som är snedfördelade skall få orimligt stort inflytande $i$ analysen har familjeinkomst -53 och egen inkomst logaritmerats. 
utsträckning risken för att man själv skall få socialbidrag som vuxen. Detta pekar på att socialbidraget inte har någon självständig effekt på barnet utan att det istället är samspelet mellan socialbidraget och personliga faktorer hos individen, samt attityder hos föräldrarna, som skapar den ökade risken att bli socialbidragstagare. Vi ser också att barn som blivit utvisade från klassrummet men som inte vuxit upp i familjer som fått socialbidrag och vars mammor hade en negativ inställning till skolk inte skiljer signifikant från jämförelsegruppen. De problem som dessa barn hade tycks ha kompenserats av andra faktorer under uppväxten. Det synes alltså vara sociala förhållandena i barnets omgivning som främst har en negativ inverkan på barnets framtidsutsikter.

\section{Diskussion}

Inledningsvis diskuterade vi kulturella respektive strukturella förklaringar till fattigdom och våra resultat tycks ge stöd åt båda typerna av förklaringar.

Men undersökningens viktigaste resultat är att de som växer upp i en familj som får socialbidrag men som inte verkar ha några andra allvarliga sociala eller personliga problem inte utvecklar någon "bidragstagaranda». Socialbidraget ser alltså inte ut att ha några "incitamentshämmande» effekter för dessa barn. Istället är det socialbidrag i kombination med andra faktorer som ökar sannolikheten att flera generationer efter varandra skall behöva socialbidrag. Analysen visar att flera faktorer under barndomen, strukturella, kulturella såväl som personliga, faktiskt ökar risken för att effekter skall verka över generationerna. Det gäller sådant som familjens ekono- mi, svaga skolresultat, kort utbildning och sträng uppfostran.

Socialbidraget är naturligtvis främst till för dem som har det sämst ställt i samhället och resultaten visar att det också är de som får bidragen. Det sociala arvet tycks också vara verksamt i den bemärkelsen att strukturella faktorer som familjens fattigdom, i samverkan med personliga problem i skolan och familjens uppfostran, påverkar barnens möjligheter att klara det vuxna livet.

De stora sociala och ekonomiska förändringarna under 1990-talet, som främst yttrat sig som massarbetslöshet, kan leda till att vi får en större andel fattiga människor som måste söka socialbidrag. Det är naturligtvis svårt att veta i vilken mån 1950- och 1960-talets uppväxtföhållanden kan jämföras med 1990-talets Sverige. Våra resultat visar dock att socialbidraget i sig antagligen inte har några långsiktigt negativa effekter för dessa människor. Men vi ser också att socialtjänsten särskilt bör uppmärksamma familjer som har andra sociala eller personliga problem så att barnen kan få goda uppväxtvillkor. Fattigdomen bekämpas sannolikt bäst genom att nästa generation också får möjligheten att försörja sig med arbete och hjälp att klara livets motgångar med ett effektivt trygghetssystem. Vi började med att citera Gustaf F. Steffen, en av pionjärerna inom svensk samhällsforskning och hans snart hundra år gamla rekommendationer gäller sannolikt fortfarande idag: "Om det sociala onda, som vi vilja utrota, i grunden bestå däruti, att det stora flertalet uppväxande medborgare födas i fattigdom samt uppfostras och tränas till fattigdom och utestängas från tillgång till så väl de materiella som de kulturella produktionsmedlen, 
så är uppenbarligen det enda rätta att vi först och främst inrikta alla våra ansträngningar på en radikal förbättring av barnens ekonomiska, sociala och kulturella levnadsförhållanden.»(Steffen 1912: 58)

\section{Bilaga}

\section{Sannolikheten att erhailla socialbidrag-ett exempel}

För att kunna jämföra olika faktorers effekter måste vi räkna om våra resultat till sannolikheter. I en logistisk regression är sannolikheten inte linjärt fördelad utan har istället formen av en S-kurva. Det innebär att effekten av ett stegs förändring $i$ en variabel är beroende av värden på de andra oberoende variablerna. För att underlätta tolkningen av modellen återger vi här en av observationerna i datamaterialet och beräknar hans risk att behöva socialbidrag som vuxen. Individen är man och har följande profil:

\section{Faktorer under uppväxten:}

Familjen fick inte socialbidrag.

Familjens inkomst låg under genomsnittet.
Mamman hade låtit honom stanna hemma fast han inte var sjuk.

Familjen var inte intresserade av religion.

Uppfostran präglades av kontroll och disciplin.

Han hade inte blivit utvisad från någon lektion.

Hans begåvning i sjätte klass var över genomsnittet.

Han har ingen utbildning över grundskolan.

\section{Faktorer i vuxen ålder:}

Inkomst under genomsnittet.

Ensamstående.

Inga egna barn.

Arbetade mindre än $20 \mathrm{t}$ /vecka.

Han var inte sjukskriven 1982/83.

När vi summerar mannens värden får vi en sannolikhet på 49 procent att han skall få socialbidrag 1982-83 men vi vet samtidigt att han faktiskt fick socialbidrag. För att illustrera effekten av att tillhöra de olika grupperna i vår kombinationsvariabel av faktorerna: socialbidrag under uppväxten mammans attityd till skolk - barnet utvisad

Tabell 3.

Sannolikheten att få socialbidrag i olika kombinationer av faktorerna socialbidrag under uppväxt, barnet utvisad från klassrummet och mammans attityd till skolk .

\section{Föräldrarnas inställning till skolk}

Aldrig accepterat skolk

Har accepterat skolk

\section{Utvisad från lektion}

Aldrig inträffat

Har inträffat

Aldrig Inträffat

Har inträffat

\section{Socialbidrag 1953-70}

$\begin{array}{ll}\text { Familjen fick } & \text { Familjen fick bidrag } \\ \text { aldrig bidrag } & \text { ett eller flera år }\end{array}$

$0,27 \quad 0,28$

$0,34 \quad 0,57$

$0,49 \quad 0,46$

0,53

0,60 
från klassrummet, flyttar vi den här individen mellan grupperna samtidigt som övriga variabler är oförändrade. Vår individ fanns i gruppen som inte hade socialbidrag under barndomen som aldrig blivit utvisad ur klassrummet men som hade en mamma som accepterat att han var hemma från skolan utan att vara sjuk. I tabell 3 ser vi hur sannolikheten att han skall bli socialbidragstagare förändras mellan de olika grupperna. För det första ser vi att han har 49 procents sannolikhet att bli socialbidragstagare i den grupp han i verkligheten tillhörde. Om vi nu tänker oss att mamman inte hade accepte- rat skolk skulle sannolikheten sjunka till 27 procent. I det fallet när individen både fick socialbidrag under uppväxten, blev utvisad från klassrummet samt haft en mamma som låtit honom skolka ökar sannolikheten till 60 procent.

Tack!

Vi vill tacka Carl-Gunnar Jansson, Walter Korpi, Karin Tengvald, Janne Flyghed, Joakim Palme, Socialvetenskaplig Tidskrifts bedömare samt expertgruppen för socialbidrag vid Centrum för utvärdering av socialt arbete för värdefulla kommentarer.

\section{Summary \\ The social inheritance in a new light- social welfare and provision condition}

Making use of an internationally unique longitudinal data set, this study tests hypotheses on the inheritance of welfare benefit recipiency as indicated by reliance on means-tested social assistance in Sweden. The original number of cohort members was 15,117 individuals born in 1953 and registered as residents of the Stockholm metropolitan area in 1963. Our data include a sub-sample of this cohort, consisting of 4,021 individuals. Over a period of three decades, between 1953 and 1984, the life situation of these individuals was repeatedly assessed through standardized interviews and surveys, as well as by official register data. Using information available in the data base, the key question of the present study is whether there has been an intergenerational transmission of recipiency of means-tested social assistance in post-war Sweden. In other words, does receiving social assistance in the family of origin increase the risk of reliance on such assistance in adulthood?

We have in the analysis disentangled interactions between welfare recipiency and other factors connected to parents, as well as child behavior in the family of origin. Our main finding was that social assistance per se cannot explain the observed intergenerational effect.

\section{Referenser}

Aldrich, John H. and Forrest D. Nelson (1984)

Linear Probability, Logit and Probit Models.

Quantitive Applications in the Social Sciences.

SAGE University Paper, vol. 45.
Andersson, Maja (1976) Hur går det för 50-talets

Stockholmspojkar?: En uppföljning av 222 vanliga skolpojkar och 100 Skåpojkar. Stockholm. Rosenlundstryckeriet. 
Bagge, Gösta (1935) Socialpolitik: Anteckningar efter professor Gösta Bagges föreläsningar 1930-1931. Stockholm. Socialinstitutet.

Becker, Gary S. and Nigel Tomes (1979) »An Equilibrium Theory of the Distribution of Income and Intergenerational Mobility." Journal of Political Economy 87(6),1153-89.

Bergmark, Åke (1991) Sociabidrag och försörjning: En studie av bidragstagande bland ensamstaende utan barn. Täby. Akademitryck AB.

Calmfors, Lars (1993) „De institutionella systemen på arbetsmarknaden och arbetslösheten." Rapport till Ekonomikommissionen, bilaga $4 \mathrm{i}$ SOU 1993:16.

Duncan, Greg J., Björn Gustafsson, Richard Hauser, Pierre Hausman, Stephen Jenkins, Hans Messinger, Ruud Muffels, Brian Nolan, JeanClaude Ray, and Wolfgang Voges (1995) Poverty and Social-assistance Dynamics in the United States, Canada, and Europe.

ESO - Expertgruppen för studier i offentlig ekonomi. (Ds 1994:81) En social försäkring. Stockholm. Finansdepartementet.

Gottfredson, Michael. och Travis Hirschi (1990) A General Theory of Crime. Stanford. Stanford University Press.

Gottschalk, Peter (1992) »The Intergenerational Transmission of Welfare Participation: Facts and Possible Causes." Journal of Policy Analysis and Management Vol. 11, No 2, 254-272.

Gottschalk, Peter (1996) "Is the Correlation in Welfare Participation Across Generations Spurious? " Journal of Public Economics 63, 125.

Halleröd, Björn (1991) Den Svenska fattigdomen. Lund. Arkiv avhandlingsserie 36.

Harrington Micheal (1962) The Other America. New York. Macmillan.

Hill, Martha S. (1985) "The Changing Nature of Poverty." Annals of the American Academy of Political and Social Sience. 479 (May), 31-47.

Hill, Martha S. and Greg J Duncan (1987) „Parental Family Income and the Socioeconomic Attainment of Children."Social Science Research 16, 39-73.

Hosmer, David W. and Stanley Lemeshow (1989)
Applied Logistic Regression. New York. John Wiley \& Sons.

Hård af Segerstad, Carl (1996) Attityder och normers betydelse för socialbidragstagandets överförande mellan generationer. C-uppsats Stockholms Universitet. Sociologiska Institutionen.

Inghe, Gunnar (1960) Fattiga i folkhemmet, en studie av laingvarigt understödda $i$ Stockholm. Uppsala. Almkvist och Wicksell.

Janson, Carl-Gunnar (1975) »The Family Study A Code Book.» Stockholm: Project Metropolitan Research Report No 4.

Janson, Carl-Gunnar (1984) „Project Metropolitan - A Presentation and Progress Report". Stockholm Project Metropolitan Research Report No 21.

Jonsson, Gustav (1969) Det Sociala Arvet. Stockholm. Tiden-Barnängen.

Kempe, Per (1976) „Varför drar man sig för att söka hjälp? « i Hans Berglind (red) Ideal och verkligheter i svensk socialvård Stockholm. Wahlström och Widstrand.

Korpi, Walter (1971) Fattigdom i välfärden: Om människor med socialhjälp. Stockholm. Tiden.

Korpi, Walter (1980) "Approaches to the study of poverty i the United States: Critical notes from a European perspective" Reprint Series no. 64. Stockholm. SOFI

Levy, Frank (1980) The Intergenerational Transfer of Poverty. Working Paper 1241-02 Washington D.C.). The Urban Institute.

Lewis, Oscar (1968). La Vida; A Puerto Rican Family in the Culture of Poverty - San Juan and New York. London. Panther Books.

McFate, Katherine, Lawson, Roger, Wilson, William Julius (red) Poverty, Inequality and the Future of Social Policy. New York Russel Sage Foundation.

McLanahan, Sara (1988) „Family Structure and Dependency: Early Transitions to Female Household Headship." Demography 25(1): 1-16.

McLanahan, Sara and Larry Bumpass (1988) "Mother-Only Families: Intergenerational Consequenses of Family Disruption. "American Journal of Sociology 94 (1), 130-52. 
McLanahan, Sara, Nan Marie S. Astone, and Nadine F Marks (1991) "The Role of Mother-Only Families in Reproduction of Poverty."In Aletha C. Huston. (ed): Children in Poverty. Child Development and Public Policy. Cambridge: Cambridge UP, 51-78.

Moffitt, Robert (1992) "Incentive Effect of the U.S. Welfare System. «Journal of Economic Litterature XXX (march 92), 1-62.

Nya Testamentet (1981) Evangelium enligt Lukas. Uddevalla. Skeab.

Pepper, John V. (1995) „Dynamics of the Intergenerational Transmission of Welfare Receipt in the United States." Journal of Family and Economic Issues 16(2/3), 265-79

Rank, Mark R. and Li-Chen Cheng (1995) „Welfare Use Across Generations: How Important Are the Ties That Bind?"Journal of Marriage and the Family 57, 673-684.

Rein, Martin \& Lee Rainwater (1978) "Patterns of Welfare Use."Social Service Review 52 (4) (12), 511-534.

Riksdagens Protokoll.(1941) AK 23/4 nr 25. Stockholm. Norstedts.

Salonen, Tapio. 1993. Margins of Welfare. Hällestad. Hällestad Press.

Santiago, Anna M. (1995) „Intergenerational and
Program-Induced Effects of Welfare Dependency: Evidence from the National Longitudinal Survey of Youth." Journal of Family and Economic Issues, 16:281-306.

Smith, William R. (1991) "Social Structure, Family Structure, Child Rearing , and Delinquency: Another Look."Stockholm: Project Metropolitan Research Report No 33.

Steffen, Gustaf F. (1912) Sociala studier. Försök till belysning av nutidens samhällsutveckling. Sjunde häftet. Stockholm. Hugo Gebers förlag.

Stenberg, Sten-Åke (1994) „Family Structure and the Inheritance of Welfare Dependence - An Inter Generational Study in Postwar Sweden." Stockholm: Project Metropolitan Research Report No 39.

Stenberg, Sten-Åke (1996) „Unemployment and Economic Hardship. A combined macro- and micro-level analysis of the relationship between unemployment and means-tested social assistance in Sweden. European Sociological Review. Under utgivande.

Tengvald, Karin (1974) Socialhjälp och försörjningsförhållanden: En studie av socialhjälpens variationer i nio kommuner i Stockholmsomrädet. Stockholm. Stockholms förortskommuners samarbetsnämnd.

Wilson, William Julius (1996) When Work Disappears. The world of the New Urban Poor. New York. Alfred E. Knopf. 